\title{
Diversity and status of migratory and resident wetland birds in Haridwar, Uttarakhand, India
}

\author{
Ashish Kumar Arya* \\ Avian Diversity and Bioacoustics Laboratory, Department of Zoology and Environmental \\ Science, Gurukula Kangri Vishwavidyalaya, Haridwar-249404 (Uttarakhand), India \\ Dinesh Bhatt \\ Avian Diversity and Bioacoustics Laboratory, Department of Zoology and Environmental \\ Science, Gurukula Kangri Vishwavidyalaya, Haridwar-249404 (Uttarakhand), India \\ Amar Singh \\ Avian Diversity and Bioacoustics Laboratory, Department of Zoology and Environmental \\ Science, Gurukula Kangri Vishwavidyalaya, Haridwar-249404 (Uttarakhand), India \\ Vikas Saini \\ Avian Diversity and Bioacoustics Laboratory, Department of Zoology and Environmental \\ Science, Gurukula Kangri Vishwavidyalaya, Haridwar-249404 (Uttarakhand), India

\section{Pushpendra Verma} \\ Avian Diversity and Bioacoustics Laboratory, Department of Zoology and Environmental \\ Science, Gurukula Kangri Vishwavidyalaya, Haridwar-249404 (Uttarakhand), India \\ Robin Rathi \\ Avian Diversity and Bioacoustics Laboratory, Department of Zoology and Environmental \\ Science, Gurukula Kangri Vishwavidyalaya, Haridwar-249404 (Uttarakhand), India \\ Parul Bhatnagar \\ Avian Diversity and Bioacoustics Laboratory, Department of Zoology and Environmental \\ Science, Gurukula Kangri Vishwavidyalaya, Haridwar-249404 (Uttarakhand), India \\ *Corresponding author. E-mail: ashishtyagi.gkv@gmail.com
}

\begin{abstract}
Migration is the seasonal habitual movement, exhibited by many avian species along a flyway from breeding to wintering grounds and vice versa all over the world. Migratory birds are very sensitive to even small changes in water level which may be affected by flood or drought on their breeding and wintering grounds. High rains during monsoon season can cause flood conditions in the lower hills and Gangetic plains including Haridwar district. In our study, conducted during last ten years (2009-2018), we covered Bheemgoda Barrage and Missarpur Ganga Ghat of Haridwar, Uttarakhand, where 46 species of Migratory (M) and Resident Migratory (RM) wetland birds were observed. Bird survey indicated that there was a significant increase $(p=0.064$, t-test) in the population of certain species such as Bhraminy Shelduck $(67 \%)$, Black Headed Gull (31\%), Gadwall (7\%), Northern Pintail (59\%), Red Crested Pochard (10\%) and Tufted Pochard (47\%) in Missarpur Ganga Ghat as compared to Bheemgoda Barrage (based on the average abundance of the species observed during study period). It may be pointed out that after flood and loss of vegetated island, there was significant decrease $(p=0.023$, t-test) in the population of species such as Black necked stork (76\%), Great crested grebe (56), Pallas gull $(47 \%)$ at Bheemgoda barrage, while some species such as Bar headed goose, Common pochard did not arrive in Bheemgoda barrage after the flood. The study would help to understand the effect of climatic change on water birds species distribution in natural and man-made wetlands.
\end{abstract}

Keywords: Avian Diversity, Migration, Population Status, Wetland birds

\section{INTRODUCTION}

Migration in bird is one of the fascinating stages of bird life subject to the changes in food availability, habitat or weather. They travel several kilometers across the geographical barriers. They don't have boundaries; many of them come to Indian subcontinent from Russia, Magnolia, China and other

\section{Article Info}

https://doi.org/

10.31018jans.v11i3.2085

Received: May 7, 2019

Revised: September 4, 2019

Accepted: September 8, 2019

\section{How to Cite}

Arya, A.K. et al. (2019). Diversity and status of migratory and resident wetland birds in Haridwar, Uttarakhand, India. Journal of Applied and Natural Science, 11(3): 732- 737 https://doi.org/

10.31018jans.v11i3.2085 
among the birds has always attracted the researchers as well as bird watchers since long ago because of its glory and science behind migration. Water bird monitoring programme is being conducted by several researchers from all over the world which makes the waterbirds one of the most studied groups of animals existing on earth (Bhatt et al. 2015). Waterbird survey plays an important role in identification of wetlands of international importance as the waterbirds are thought to be a natural bio-indicators, and provides the basis for the so-called $1 \%$ criterion, as described any wetland which continuously holds $1 \%$ or more of a waterbird population is considered to be internationally important under the Ramsar Convention on Wetlands also for identification of priorities for conservation and research for maintenance of wetland bird biodiversity (Kumar and Bhatt 2000). Water birds have many ecological values like aesthetic, sporting and economic values. Waterfowl has been defined as the species of birds that are "ecologically dependent upon wetlands" and "water bird" has been defined as being synonymous with waterfowl by the Ramsar Convention defines. Waterbird consists the families like Anatidae, Anhimidae, Anhingidae, Aramidae, Ardeidae, Balaenicipitidae, Burhinidae, Charadriidae, Ciconiidae, Dromadidae, Gaviidae, Glareolidae, Gruidae, Haematopodidae, Heliornithidae, Eurypygidae, Ibidorhynchidae, Laridae, Pedionomidae, Pelecanidae, Phalacrocoracidae, Phoenicopteridae, Podicipedidae, Rallidae, Recurvirostridae, Rostratulidae, Rynchopidae, Scolopacidae, Scopidae, Sternidae Thinocoridae, Threskiornithidae etc. (Delany and scott 2002).

Studies have shown that wetlands of India are being degraded due to developmental activities, population growth and the over-exploitation of natural resources (Islam and Rahmani, 2004). The Indian Himalayan region has been explored and well-studied for its biological diversity and ecological values (Bhattacharjee and Bargali 2012). So far about 1313 species of birds have been identified in India and the Indian subcontinent which contributes about $13 \%$ of world avian population (Grimmett et al. 2013). The western part of Indian Himalayan Region has been recognised as Endemic Bird Area (EBA 128) by Bird Life International (2003) as it shows high regional endemism. It also has 27 Important Bird Areas (IBAs) (Islam and Rahmani 2004; Saini et al. 2017).

The populations of several duck species are also declining in India (Islam and Rahmani 2004; Delany and Scott 2006). About 1,186 species of bird (roughly $12 \%$ of world's avian species) are threatened with global extinction, out of which 182 are Critically Endangered which are facing a very high risk of complete extinction in near future. Wetlands are very important for conservation of waterbirds as $20 \%$ population of the threatened bird species of Asia inhabit in wetlands. It is about twice of the globally threatened waterbird species $(10 \%)$. Many avian species are very limited in population and hence these are very close to extinction because of disturbance, destruction or conversion of their habitats and hunting by humans and animals. Of the major waterbird families, the family Anatidae (the ducks, swans and geese) is among the most extensively studied and holding the greatest attraction for man. Illustrations of geese are found in five thousand-year-old Egyptian tombs. Many legends have evolved around wildfowl, particularly swans have been regarded as sacred and possessing magical qualities since ancient times all over the world (Kumar and Bhatt 2000; Saini et al. 2017).

Habitat change as conversion and degradation of natural wetlands are major causes of population decline of waterbird of the Asia, which affect nearly all the species categorised as Endangered, Critically endangered, and Vulnerable. Exploitation by humans is another reason for the population decline of waterbirds which affect more than $50 \%$ of all threatened bird species. Among this hunting for food and sport contribute $70 \%$ and $30 \%$ are captured for the wild bird trade. The major causes of wetland degradation are drainage and conversion, including the infilling (or 'reclamation') for agriculture and aquaculture purposes. Dams and irrigation projects are also negatively affecting wetlands (Tak et al. 2010). In this context, an attempt has been made to understand the present status of the migratory water birds of Ganga Valley, by compiling information of our study and from the studies based on fieldwork conducted by the other researchers about the migratory birds.

\section{MATERIALS AND METHODS}

Study area: The present study was conducted during 2009 to 2018, in the foothills of Himalaya of district Haridwar, Uttarakhand. Comparative study was done between natural wetland (Missarpur) and man-made (Bheemgoda) wetlands. Indian wetlands have been categorized biogeographically by Hussain and Roy 1993. The Bheemgoda Barrage, 17 (water-storage) barrage, is situated at the upstream region $\left(29^{\circ} 58^{\prime} \mathrm{N}, 78^{\circ} 13^{\prime} \mathrm{E}, 249.7 \mathrm{~m}\right.$ asl) between the Neeldhara and the tributaries of the Ganga river (Fig. 1A) under biogeographic province 4.8.4 (Indo-Gangatic Monsoon forest), covering an area of about $2.5 \mathrm{~km}^{2}$ while Missarpur is a natural wetland situated $8 \mathrm{~km}$ away at the downstream (Fig. 1B) from Bheemgoda Barrage comprising an area of about $1.5 \mathrm{~km}^{2}$, under biogeographic province 4.8.4 (Indo-Gangatic Monsoon forest). Bheemgoda barrage area has some aquatic vegetations of Potomageton pectinatus, Eichhornia crassipes and Typha elephantine with a tree species, Dalbergia sissoo is common 
around the wetland. Contrary to this, Missarpur wetland has dominant aquatic vegetation of Eichhornia crassipes, Typha elephantine, Ipomea fistulosa, Potomageton pectinatus and Dalbergia sissoo with mixed tree species. Haridwar has three prominent seasons like winter (October to March), summer (April to June) and Monsoon (July to September) and the temperature ranges from minimum of $4^{\circ} \mathrm{C}$ in winter to a maximum $44^{\circ}$ $\mathrm{C}$ in summer.

Field data collection: The study was conducted between November 2009 and March 2018 at Bheemgoda barrage and Missarpur wetland of Haridwar, Uttarakhand. Out of these wetlands Missarpur is a natural wetland while, Bheemgoda barrage is a manmade wetland. Surveys were carried out for migratory birds during the morning (06.30 - 11.00) and evening (15.30 - 17.00) period from October to March. Population was estimated with the help of point count method (Bibby et al.
2000). During the survey, we walked along the bank of river and selected vantage points $20-30$ meter away from birds. Regular field visits were done through the study period on alternate days, while excessive foggy and rainy days were avoided as the visibility was decreases during this period. Migratory birds were identified with the help of field guide books viz. Ali (2002), Grimmett et al. (2013), Mohan and Sondhi (2014) and photographs of birds were taken for the record.

Data analysis: 'T'-test was applied to estimate the significant difference between natural and manmade

wetland habitats. Mean abundance was calculated on the basis of the species composition of an organism of a particular kind relative to the total number of organisms in the area. The percentage of winter migratory and resident birds was calculated on the basis of total number of species. The Shannon- Weavers index $\left[\mathrm{H}^{\prime}=-\Sigma \mathrm{pi}(\mathrm{In} \mathrm{pi})\right]$ was
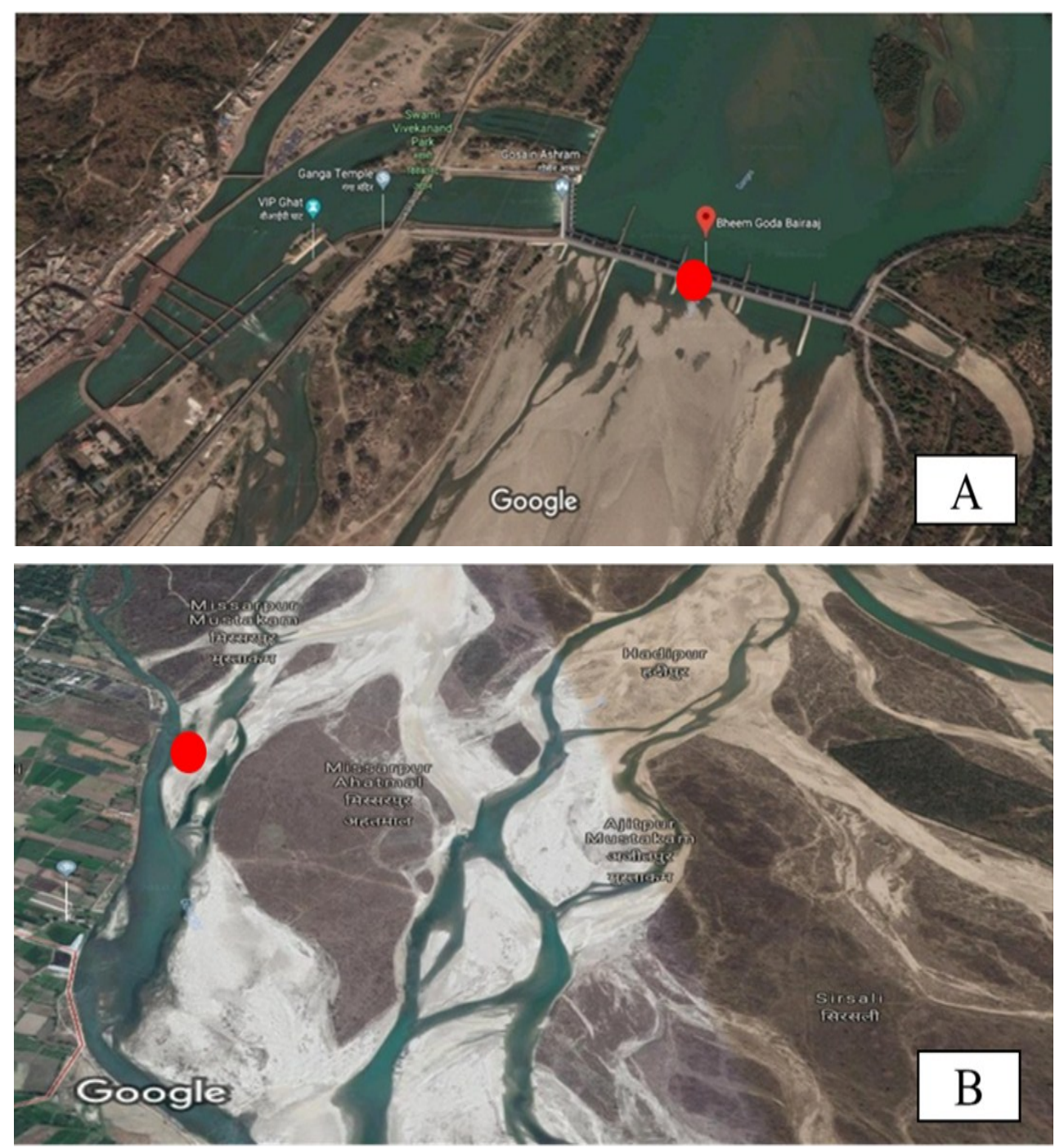

Fig 1. Showing the study area in Himalayan foothills of district Haridwar, Uttarakhand, India. A. Bheemgoda barrage B. Missarpur Natural Wetland in the Ganga River, India (Source: Google earth). 


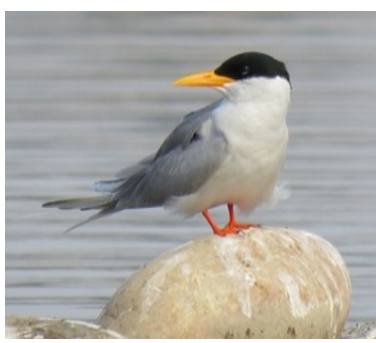

A. River Tern

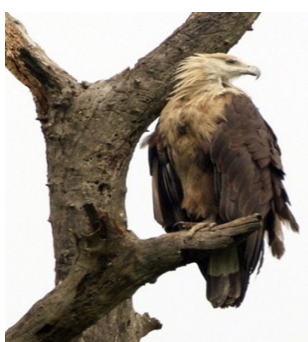

E. Pallas fish eagle

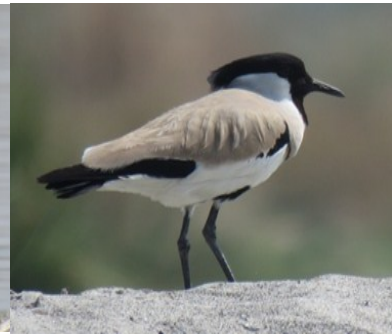

B. River Lapwing

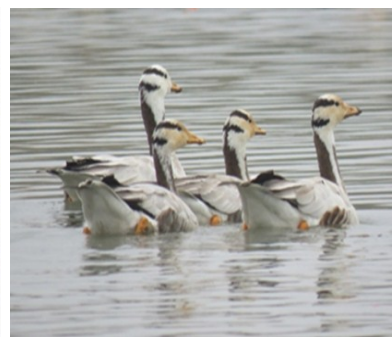

F. Bar Headed Goose

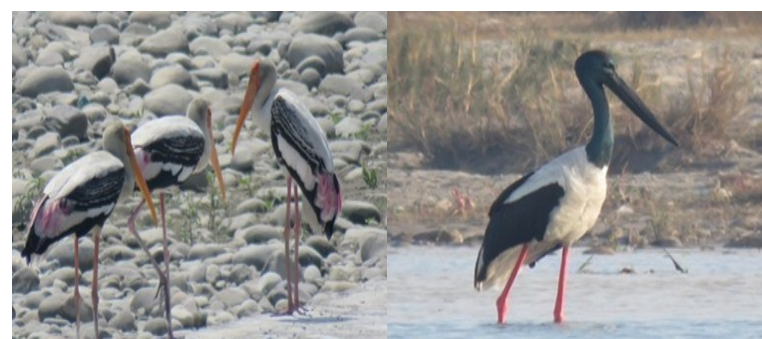

C. Painted Stork

D. Black Necked Stork

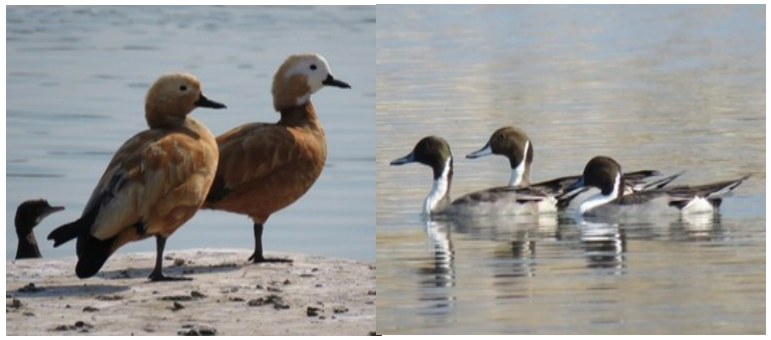

G. Ruddy Shelduck

Fig 2. Water birds at natural and man-made wetland of Haridwar District, Uttarakhand, India. A. River Tern B. River Lapwing C. Painted Stork D. Black Necked Stork E. Pallas fish eagle F. Bar Headed Goose G. Ruddy Shelduck H.Northern pintail.

used to calculate species diversity indices (Shannon and Weaner 1949). Software was also used for statistical analysis.

\section{RESULTS AND DISCUSSION}

The avian diversity indices between natural and manmade wetland habitat showed that natural wetland (Missarpur wetland) had maximum diversity values in comparison to manmade wetland (Bheemgoda Wetland) of Haridwar Dist. (Table 1). The abundance of migratory bird species between
Bheemgoada Barrage and Missarpur Ganga Ghat on the basis of status of avifauna before and after flood occurred during 2010 is given in Table 2.

The present study showed forty six avian species (18024 individuals) belonging to 16 families at manmade Bheemgoda Barrage and natural Missarpur wetland area of Haridwar District. Among 46 waterbird species, 24 species were residential birds and 22 were reported as winter visitors (Table 3 ). The percentage of water bird species and residential bird species was found to be

Table 1. Comparison of diversity indices between manmade and natural wetland habitat at Haridwar (Uttarakhand).

\begin{tabular}{lll}
\hline Parameters & $\begin{array}{l}\text { Bheemgoda Barrage } \\
\text { (Manmade wetland) }\end{array}$ & $\begin{array}{l}\text { Missarpur } \\
\text { (Natural Wetland) }\end{array}$ \\
\hline Location (latitude and longitude) & $29^{\circ} 58^{\prime} \mathrm{N}, 78^{\circ} 13^{\prime} \mathrm{E}$ & $29^{\circ} 89^{\prime} \mathrm{N}, 78^{\circ} 14^{\prime} \mathrm{E}$ \\
Elevation (m asl) & $320 \mathrm{~m}$ asl & $314 \mathrm{~m}$ asl \\
Shannon's Diversity (H') (mean diversity) & 1.55 & 2.19 \\
No. of Individual & 8381 & 9643 \\
No. of Migrant species (Non breeder) & 12 & 19 \\
No. of Residential species (Breeder) & 16 & 24 \\
\hline
\end{tabular}

Table 2. Mean Abundance of some migratory species at Bheemgoda Barrage and Missarpur Ghat in Ganga Valley after flood in Bheemgoda Barrage at Haridwar (Uttarakhand).

\begin{tabular}{|c|c|c|c|c|c|c|c|}
\hline \multirow[t]{2}{*}{$\begin{array}{l}\text { S. } \\
\text { N. }\end{array}$} & \multirow{2}{*}{$\begin{array}{l}\text { Common } \\
\text { Name of } \\
\text { species }\end{array}$} & \multicolumn{2}{|c|}{$\begin{array}{l}\text { Mean Abundance before } \\
\text { flood (2009) }\end{array}$} & \multicolumn{2}{|c|}{$\begin{array}{c}\text { Mean Abundance after } \\
\text { flood }(2011-15)\end{array}$} & \multicolumn{2}{|c|}{$\begin{array}{c}\text { Mean Abundance during } \\
2016-2018\end{array}$} \\
\hline & & $\begin{array}{l}\text { Bheemgoda } \\
\text { Barrage }\end{array}$ & $\begin{array}{l}\text { Missarpur } \\
\text { Ganga } \\
\text { Ghat }\end{array}$ & $\begin{array}{l}\text { Bheemgoda } \\
\text { Barrage }\end{array}$ & $\begin{array}{l}\text { Missarpur } \\
\text { Ganga } \\
\text { Ghat }\end{array}$ & $\begin{array}{l}\text { Bheemgoda } \\
\text { Barrage }\end{array}$ & $\begin{array}{l}\text { Missarpur } \\
\text { Ganga } \\
\text { Ghat }\end{array}$ \\
\hline 1. & $\begin{array}{l}\text { Ruddy } \\
\text { Shelduck }\end{array}$ & 60.50 & 25.55 & 12.5 & 60.18 & 20.5 & 65.55 \\
\hline 2. & Pintail & 14.63 & 20.15 & 10.00 & 35.73 & 7.17 & 36.14 \\
\hline 3. & Mallard & 7.87 & 3.75 & 7.39 & 13.69 & 6.15 & 12.5 \\
\hline 4. & $\begin{array}{l}\text { Red Crested } \\
\text { Pochard }\end{array}$ & 13.50 & 13.47 & 6.70 & 14.97 & 13.00 & 15.5 \\
\hline 5. & Common Teal & 22.97 & 14.00 & 13.33 & 17.23 & 12.5 & 14.5 \\
\hline
\end{tabular}


Table 3. Avian species observed at natural and man-made wetlands in Haridwar (Uttarakhand)

\begin{tabular}{|c|c|c|c|c|c|c|}
\hline Family & Common Name & Zoological Name & $\begin{array}{l}\text { Sta- } \\
\text { tus }\end{array}$ & $\begin{array}{l}\text { Mis- } \\
\text { sarpur } \\
\text { (Natural } \\
\text { wetland) }\end{array}$ & $\begin{array}{l}\text { Bheemgo- } \\
\text { da } \\
\text { barrage } \\
\text { (Man-made } \\
\text { wetland) }\end{array}$ & $\begin{array}{l}\text { IUCN } \\
\text { Sta- } \\
\text { tus }\end{array}$ \\
\hline \multirow[t]{4}{*}{ Accipitridae } & Black Kite & Milvus migrans & $\mathrm{R}$ & + & + & $\mathrm{LC}$ \\
\hline & Crested Serpent Eagle & Spilornischeela & $\mathrm{R}$ & + & + & LC \\
\hline & Bonelli's eagle & Aquila fasciata & $\mathrm{R}$ & + & + & LC \\
\hline & Pallas's fish eagle & Haliaeetus leucoryphus & WM & + & - & EN \\
\hline \multirow[t]{3}{*}{ Alcedinidae } & Blue-eared Kingfisher & Alcedomeninting & $\mathrm{R}$ & + & - & LC \\
\hline & Pied Kingfisher & Cerylerudis & $\mathrm{R}$ & + & + & LC \\
\hline & $\begin{array}{l}\text { White-throated King- } \\
\text { fisher }\end{array}$ & Halcyon smyrnensis & $\mathrm{R}$ & + & + & LC \\
\hline \multirow[t]{13}{*}{ Anatidae } & $\begin{array}{l}\text { Black-crowned Night } \\
\text { Heron }\end{array}$ & Nycticoraxnycticorax & $\mathrm{R}$ & + & + & LC \\
\hline & Common Merganser & Mergus merganser & WM & + & + & LC \\
\hline & Eurasian Teal & Anas crecca & WM & + & + & LC \\
\hline & Gadwall & Anas Strepera & WM & + & + & LC \\
\hline & Mallard & Anas platyrhynchos & WM & + & - & LC \\
\hline & Marbled Duck & $\begin{array}{l}\text { Marmaronettaan- } \\
\text { gustirostris }\end{array}$ & $\mathrm{R}$ & + & + & LC \\
\hline & Northern Pintail & Anas acuta & WM & + & + & LC \\
\hline & Red-crested Pochard & Nettarufina & WM & + & + & LC \\
\hline & Ruddy Shelduck & Tadornaferruginea & WM & + & + & LC \\
\hline & Tufted Duck & Aythyafuligula & WM & - & + & LC \\
\hline & Indian Spot-billed Duck & Anas poecilorhyncha & $\mathrm{R}$ & + & - & LC \\
\hline & Bar-headed Goose & Anser indicus & WM & + & - & LC \\
\hline & Red-crested pochard & Nettarufina & WM & + & - & LC \\
\hline \multirow[t]{4}{*}{ Ardeidae } & Grey Heron & Ardeacinerea & $\mathrm{R}$ & + & + & LC \\
\hline & Indian Pond Heron & Ardeolagrayii & $\mathrm{R}$ & + & + & LC \\
\hline & Great Egret & Casmerodiusalbus & $\mathrm{R}$ & + & + & LC \\
\hline & Western Cattle Egret & Bubulcus ibis & $\mathrm{R}$ & + & - & LC \\
\hline Charadriidae & Red-wattled Lapwing & Vanellus indicus & $\mathrm{R}$ & + & - & LC \\
\hline & River Lapwing & Vanellusduvaucelii & $\mathrm{R}$ & + & + & NT \\
\hline Ciconiidae & Woolly-necked Stork & Ciconia episcopus & $\mathrm{R}$ & + & + & Vul \\
\hline & Black-necked stork & $\begin{array}{l}\text { Ephippiorhynchusasiat- } \\
\text { icu }\end{array}$ & WM & + & + & NT \\
\hline & Black stork & Ciconia nigra & WM & - & + & LC \\
\hline & Painted stork & Mycterialeucocephala & WM & - & + & NT \\
\hline Laridae & Pallas's Gull & Ichthyaetusichthyaetus & WM & + & - & LC \\
\hline & Black-headed gull & $\begin{array}{l}\text { Chroicocephalusridibun- } \\
\text { dus }\end{array}$ & WM & + & + & LC \\
\hline & Steppe Gull & Laruscachinnans & WM & + & - & LC \\
\hline & River tern & Sterna aurantia & WM & + & - & NT \\
\hline Motacillidae & White Wagtail & Motacilla alba & $\mathrm{R}$ & + & - & LC \\
\hline & Western yellow wagtail & Motacilla flava & WM & + & - & LC \\
\hline Pandionidae & Western Osprey & Pandion haliaetus & WM & + & + & LC \\
\hline Phalacrocoraci- & Little Cormorant & Microcarboniger & $\mathrm{R}$ & + & + & LC \\
\hline & Great Cormorant & Phalacrocorax carbo & $\mathrm{R}$ & + & + & LC \\
\hline Podicipedidae & Great Crested Grebe & Podicepscristatus & WM & + & + & LC \\
\hline & Little Grebe & Tachybaptusruficollis & $\mathrm{R}$ & + & + & LC \\
\hline Recurvirostridae & Black-winged stilt & Himantopushimantopus & $\mathrm{R}$ & + & - & LC \\
\hline & Pied avocet & Recurvirostraavosetta & WM & + & - & LC \\
\hline Scolopacidae & Common sandpiper & Actitishypoleucos & $\mathrm{R}$ & + & + & LC \\
\hline $\begin{array}{l}\text { Threskiornithi- } \\
\text { dae }\end{array}$ & Red-naped ibis & Pseudibispapillosa & $\mathrm{R}$ & + & + & LC \\
\hline Muscicapidae & Black redstart & Phoenicurusochruros & $\mathrm{R}$ & + & - & LC \\
\hline
\end{tabular}

R: Resident; WM: Winter Migratory; LC: Least Concern; NT: Near Threatened; Vul: Vulnerable

$53.33 \%$ and $47.22 \%$ respectively.

Bird survey indicated that there was a significant increase ( $p=0.064$, t-test) in the population of certain species such as Bhraminy Shelduck
$(67 \%))$, Black Headed Gull (31\%), Gadwall (7\%), Northern Pintail (59\%), Red Crested Pochard $(10 \%)$ and Tufted Pochard $(47 \%)$ in Missarpur Ganga Ghat as compared to Bheemgoda Barrage 
(based on the average abundance of the species observed during study period). It may be pointed out that after flood and loss of vegetated island, there was significant decrease $(p=0.023$, t-test $)$ in the population of species such as Black necked stork $(76 \%)$, Great crested grebe $(56 \%)$, Pallas gull $(47 \%)$ at Bheemgoda barrage, while some species such as Bar headed goose, Common pochard did not arrive in Bheemgoda barrage after the flood.

The habitat of the area like vegetation composition and cover are the important factors that are responsible for tandcoerhe selection of the habitat and distribution, diversity and richness of the water bird species. Rajpar et al. (2011) reported that vegetation composition influences the variety of food resources which increase the abundance of the waterbird species in the area. The deeper water supports the rich density of some species especially of ducks prefes deep open water body for foraging (Saikia and Bhattacharjee, 1993). It has been reported that the population of water residential and migrant birds have declined significantly. (Saini et el 2017). The study showed that among the water bird species, four species viz; River Tern (Fig. 2A) River Lapwing (Fig. 2B), Painted Stork (Fig. 2C) Black-necked stork (Fig. 2 $D)$, are under near threaten category (IUCN) and one species viz Pallas's fish eagle (Fig. 2E) under endangered (IUCN) category at man-made and natural wetland respectively.

The presence of Bar-headed Goose (Anser indicus) (Fig. 2F) at Misserpur wetland arrived in winter season from central part of Asia, thereby, indicating that natural wetland favourable for water migratory birds. Ruddy Shelduck (Fig. 2G) and Northern Pintail (Fig. 2H) are the winter migrants in north region of Indian Subcontinent as reported earlier by Bhatt et al. ( 2014). The presence of near threatened species in wetlands of Haridwar indicates the need of conservation effort in this area for water bird species. The restoration practice of wetland sites will save the host variety of plant life, such as emergent vegetation, which can provide shelter for waterbirds. Earlier studies have also reported that both natural (Missarpur) and man-made wetlands (Bheemgoda) are good habitats for water birds and migratory species (Saini et al., 2017).

\section{Conclusion}

Present study suggests that the natural wetland (Misserpur Wetland) of the Haridwar district was more suitable for water bird species as compared to man-made wetland (Bheemgoda Wetland). The natural wetland provided a variety of food, shelter and roosting site for bird species. After the flood in the area of Bheemgoda Wetland, during 2010, most of the water birds shifted to natural wetland due to lack of shelter. The study will help in con- servation and management of the distribution of water birds species in natural and man-made wetlands in the coming time.

\section{REFERENCES}

1. Ali, S. (2002). The book of Indian birds Oxford University press. New Delhi, 326pp.

2. Bhattacharjee, A., and Bargali, H. S. (2012). Status and trend of Water birds in wetlands around Corbett. The Corbett Foundation. India. Technical Report submitted to Uttarakhand State Forest Department.

3. Bibby, C. J., Burgess, N. D., Hill, D. A., and Mustoe, S. (2000). Bird census techniques. Elsevier.

4. Bhatt, D., Sethi, V. K., Sharma S., Kumar, A., Saini V. and Singh A. (2015) Water birds of selected wetlands of Uttarakhand. ENVIS, WII, Dehradun.

5. Borale, R. P., Patil, J. V., and Vyawahare, P. M. (1994). Study of population of local migratory (Aquatic) birds observed in and around Dhule. Maharastra. Pavo, 32, 81-86.

6. Delany, S., and Scott, D. (2002). Waterbird population estimates. Wetlands International, Wageningen (PaísesBajos).

7. Grimmett, R., Inskipp, C., andlnskipp, T. (2013). Birds of the Indian Subcontinent: India, Pakistan, Sri Lanka, Nepal, Bhutan, Bangladesh and the Maldives. Bloomsbury Publishing.

8. Hussain, S. A., and De Roy, R. (1993). Directory of Indian wetlands. WWF-India, New Delhi and A WB, Kuala Lumpur.

9. Bird Life Internationa(2003). BirdLife's online World Bird Database: the site for bird conservation. Bird Life International Cambridge,, UK.

10.Islam, M. Z., and Rahmani, A. R. (2004). Important Bird Areas in India: priority sites for conservation. Indian Bird Conservation Network: Bombay Natural History Society and Birdlife International (UK), 1133.

11.Kumar, A., and Bhatt, D. (2000). Status of migratory avifauna of subtropical wetland in Ganga Valley, Haridwar, India. Annals of Forestry, 8(1), 17-24.

12.Mohan, D., and Sondhi, S. (2014). An updated checklist of the birds of Uttarakhand. Uttarakhand Forest Department, Dehradun.

13.Rajpar, M. N., and Zakaria, M. (2011). Bird species abundance and their correlationship with microclimate and habitat variables at Natural Wetland Reserve, Peninsular Malaysia. International Journal of Zoology, DOI: http://dx.doi.org/10.1155/2011/7 58573

14.Saikia, P., and Bhattacharjee, P. C. (1993). Status, diversity and decline of waterbirds in Brahmaputra Valley, Assam, India. Bird Conservation, Strategies for the Nineties and Beyond. Ornithological Society of India, Bangalore, 20-27.

15.Saini, V., Joshi, K., Bhatt, D., Singh, A., and Joshi, R. (2017). Waterbird species distribution between natural and manmade wetland in Himalayan foothills of Uttarakhand, India. Biodiversitas Journal of Biological Diversity, 18(1). DOI: 10.13057/biodiv/d180144

16.Shannon, C. E., and Weaver, W. (1949). The mathematical theory of communication (Urbana, IL. University of Illinois Press IL.

17.Tak, P. C., Sati, J. P., and Rizvi, A. N. (2010). Status of waterbirds at Hathnikund Barrage wetland, Yamunanagar District, Haryana, India. Journal of Threatened Taxa, 841-844. DOI: https://doi.org/10.11609/ JoTT.02200.841-4 